\title{
Predation on Encapsulated Larvae by Adults: Effects of Introduced Species on the Gastropod Ilyanassa obsoleta
}

\author{
G. A. Brenchley \\ Department of Ecology and Evolutionary Biology, University of California, Irvine, California 92717, USA • \\ and \\ Marine Biological Laboratory, Woods Hole, Massachusetts 02543, USA
}

\begin{abstract}
The abundant and ubiquitous marine snail Ilyanassa obsoleta is not known to be a major food item of any predator. Several species prey heavily upon its egg capsules, which spend 1 or more wk attached to solid objects in the intertidal zone. Predation losses in caging experiments conducted in Barnstable Harbor, Masschachusets (USA) averaged $52 \%$, but in 1 case exceeded $85 \%$ in $10 \mathrm{~d}$. Thus predation on encapsulated larvae of this population equals or exceeds that on planktonic stages. Much of this mortality was associated with introduced species. Predation rates (egg capsules individual ${ }^{-1} 2$ $\mathrm{d}^{-1}$ ) measured in the laboratory were: native hermit crabs Pagurus longicarpus, 141; introduced green crabs Carcinus maenas, 330; and introduced periwinkles Littorina littorea, 11. L. littorea was the most abundant egg consumer in the mid-intertidal zone where most egg capsules were laid. Capsules detached by the predators released larvae as did whole capsules defecated by L. littorea. Two native predators on molluscs, moonsnails (Polinices duplicatus) and juvenile horseshoe crabs (Limulus polyphemus), did not eat egg capsules.
\end{abstract}

\section{INTRODUCTION}

For species with planktonic larvae, maximum mortality is generally associated with the plankton (e. g. Bayne, 1976; Levinton, 1982). Emphasis has been placed on mortality at settlement due to adults or established individuals (Thorson, 1950; Mileikovsky, 1974; Woodin, 1976, 1979; Wilson, 1980; Hunt, 1981). Established individuals may also prey on eggs or larvae before they reach the plankton (MacKenzie, 1961; Hurst, 1965; Perron, 1975; Race, 1979; Tallmark, 1980). Many soft-bottom polychaetes and gastropods do not directly shed their eggs, sperm, or larvae into the water column, but rather deposit eggs on the bottom in capsules or gelatinous masses (Pechenik, 1979). The relative importance of mortality on encapsulated larvae is not generally known. In this paper, I examine the importance of predation on egg capsules of the common marine gastropod Ilyanassa obsoleta.

Ilyanassa obsoleta attaches its egg capsules to many 'solid' surfaces in the intertidal zone, including wood,

\footnotetext{
- Address for correspondence
}

algae, shells, eel grass, and marsh peat (Tyron, 1882; Dimon, 1905; Scheltema, 1962; Pechenik, 1978). In Barnstable Harbor, Massachusets (USA), surfaces suitable for egg capsule deposition are so rare (Pechenik, 1978 ) as to limit the reproducitve output of some populations of $I$. obsoleta (Brenchley, 1981). Egg capsules protect developing embryos from low-salinity stess (Pechenik, 1982), but are not necessary for development and do protect from desiccation (Pechenik, 1978). The encapsulated larvae are then exposed to intertidal predators over the next 1 to $3 \mathrm{wk}$, depending on seawater temperatures which regulate development (Scheltema, 1967). After 1 to $2 \mathrm{wk}$ in the plankton, the larvae return to creep and swim near the bottom for another $2 \mathrm{wk}$.

Juvenile and adult Ilyanassa obsoleta are preyed upon by the green crab Carcinus maenas (Stenzler and Atema, 1977; Ashkenas and Atema, 1978), the moonsnails Polinices duplicatus and Lunatia heros (Atema and Burd, 1975; Stenzler and Atema, 1977), and migratory birds (Recher, 1966; Anderson, 1970), but $I$. obsoleta is not believed to be one of their major foods items. Survivorship of individuals attaining sexual 
maturity (ca. 2 yr) is high. The greatest source of adult mortality is associated with trematode parasites (Miller and Northup, 1926; Grodhaus and Keh, 1958; Gambino, 1959; Sindermann, 1960; Stunkard, 1961; Schaefer et al., 1968; Stambaugh and McDermott, 1969; Vernberg, 1969; Smith, 1980). These parasites can affect the locomotion, reproduction, sexuality, growth, and physiological tolerances in older snails in particular.

In Barnstable Harbor, Carcinus maenas, Pagurus longicarpus, Littorina littorea, and 2 molluscan predators - Polinices duplicatus (Edwards, 1974) and Limulus polyphemus (Green and Hobson, 1970) - were commonly found near surfaces where egg capsules were laid. Other predators in the Harbor such as Lunatia heros and Natica clausa, were not common in the study site. This research, part of a study on the migration and aggregation of mud snails, was undertaken to determine (1) which, if any, of these species prey on eggs of Ilyanassa obsoleta and (2) the extent of such predation in nature.

\section{METHODS AND MATERIALS}

The study was conducted during May and June, 1981 on a sandy intertidal flat between Indian Trail and Bone Hill Road in Barnstable Harbor, Massachusetts $\left(41^{\prime} 43^{\circ} \mathrm{N} ; 70^{\prime} 20^{\circ} \mathrm{W}\right)$. Laboratoy experiments were done at the Marine Biological Laboratory.

\section{Laboratory Experiments}

The 5 suspected predators (Table 1) were collected in the mid-intertidal zone. Except for Littorina littorea, each specimen was placed in a glass finger bowl (bottom area, $70 \mathrm{~cm}^{2}$ ) with a 5 to $10 \mathrm{~mm}$ layer of sand collected from the Harbor, and a 1 to $2 \mathrm{~cm}$ strand of Codium or Zostera bearing approximately 500 intact Ilyanassa obsoleta egg capsules, collected the same day. These capsules contained early embryos with no velum pigmentation or shell visible. The bowls were covered with mesh and submerged in large tables with running seawater. The number of broken and empty egg capsules was counted every 1 to $2 d$ for the next 4 to $5 \mathrm{~d}$.

Two sets of experiments were designed for Littorina littorea which migrated upwards in the submerged laboratory containers. In the first, 4 adult Ilyanassa obsoleta (18 to $22 \mathrm{~mm}$ in shell length) were added to each of 12 glass bowls and given several substrates on which to lay egg capsules (rock, shell, and Codium or peat). After $10 \mathrm{~d}$, the mudsnails were removed, and 6 littorines added to each bowl. The number of intact egg capsules remaining on each surface was recorded every $2 \mathrm{~d}$ for the next $8 \mathrm{~d}$. In the second experiment, 4 adult mud snails were added to each of 24 compartments $(4 \times 4 \times 4 \mathrm{~cm})$ of a plastic storage box and again given several substrates for egg laying. The walls of the box were perforated and fitted with 4 seawater hoses to ensure adequate circulation. The water level was maintained $1 \mathrm{~cm}$ below the top of the box. After $10 \mathrm{~d}$, egg capsules were counted, the mud snails removed, and 2 littorines added. As before, the number of egg capsules remaining on each surface was recorded every $2 \mathrm{~d}$ for $8 \mathrm{~d}$.

Seawater temperatures rose from $14{ }^{\circ} \mathrm{C}$ to $18{ }^{\circ} \mathrm{C}$ in mid-June. At these temperatures, Ilyanassa obsoleta embryos emerge from capsules in 2 to several wk (Scheltema, 1967). Egg capsules from which larvae have naturally emerged can be identified by the absence of the opercular plug (Pechenik, 1975). To ensure that empty capsules found in the containers did not reflect natural emergence, experiments were terminated when larval within the capsules had acquired a purple velar pigmentation.

The successful completion of development in egg capsules defecated by Littorina littorea and broken by Carcinus maenas and Pagurus longicarpus was also examined. For 24 h $L$. littorea were fed mud snails egg capsules held in abundance within bowls. The periwinkles often trapped uneaten capsules behind their opercula when moved from one bowl to another. Therefore, the snails were examined for adhering capsules before they were transferred to a second clean bowl of seawater. Capsules collected the following day from their feces were moved to room temperature $\left(24{ }^{\circ} \mathrm{C}\right)$ to accelerate development and examined periodically until all control capsules had hatched. $C$. maenas and $P$. longicarpus did not ingest the capsule itself. Broken and detached capsules were collected from bowls containing each predator species, moved to room temperature, and examined periodically for larval emergence.

\section{Field Experiments}

Censuses of Ilyanassa obsoleta and the suspected predators were conducted on the Barnstable Harbor sand flat in June 1981. Numbers of $I$. obsoleta, Littorina littorea, and Pagurus longicarpus on the surface or buried 2 to $3 \mathrm{~cm}$ in the sand were counted in 24 to 60 replicate $0.25 \mathrm{~m}^{2}$ quadrats, (1) at the marsh edge and adjacent flat of the upper tidal zone, (2) in tide pools and exposed flats of the mid-intertidal zone, and (3) in the low intertidal Zostera bed. The abundance of Carcinus maenas was determined during flood tides with the aid of mask and snorkle. Counts were made in the 
mid-intertidal zone on the exposed ends of 156 Diopatra cuprea tubes (= tube-caps) which had egg capsules already attached, or I. obsoleta actively depositing egg capsules, or no egg capsules or mud snails present.

A field experiment was conducted to measure rates of predation on egg capsules in a tide pool near Indian Trail. The population of Ilyanassa obsoleta, about 20000 individuals, remained within that pool all summer as it did the previous year (Brenchley, 1980). Most egg capsules were laid on 9 small clumps of eel grass and a few were laid on the stalks of the cord grass Spartina alternaflora, low in the rank of preferred substrates (Brenchley, 1981). Masses of egg capsules laid on Codium, a highly preferred substrate, were collected from the mid-intertidal zone. Codium, obtained from a pile of actively reproducing mud snails, was selected because variability in numbers of egg capsules per unit length was found to be small in the laboratory experiments. One strand was cut into 10, 1$\mathrm{cm}$ lengths so that initial numbers of egg capsules per unit length could be estimated. The remaining was cut into $5-\mathrm{cm}$ lengths, and tied to wooden stakes in the tide pool. Eight pieces were left uncaged and 6 strands were enclosed within two $0.1 \mathrm{~m}^{2} \times 15 \mathrm{~cm}$ high cages constructed of plastic mesh $(0.6 \mathrm{~mm}$ openings). Each strand was collected and preserved on Day 10 (June $20)$ in alcohol. The number of egg capsules on each strand was counted.

\section{RESULTS}

\section{Laboratory Results}

Carcinus maenas and Pagurus longicarpus were voracious predators on mud snail eggs, ingesting the contents of an average of 330 and 141 capsules every 2 $\mathrm{d}$ (Table 1). These rates of predation are exaggerated

Table 1 Ilyanassa obsoleta. Rates of consumption on egg capsules in laboratory studies. Mean number of eggs individual $^{-1} 2 \mathrm{~d}^{-1}$; $\mathrm{SD}$ : standard deviation. Brackets indicate number of specimens used; $\mathrm{N}$ : counts of predation rates

\begin{tabular}{|c|c|c|c|c|c|}
\hline \multirow{2}{*}{\multicolumn{2}{|c|}{ Species }} & \multirow{2}{*}{$\begin{array}{l}\text { Size } \\
(\mathrm{mm})\end{array}$} & \multicolumn{3}{|c|}{ Consumption rate } \\
\hline & & & $N$ & Mean & SD \\
\hline Pagurus longicarpus & (21) & $5.0-6.9^{1}$ & 35 & 141 & 46 \\
\hline Carcinus maenas & (9) & $20-23^{2}$ & 10 & 330 & 103 \\
\hline Littorina littorea & (96) & $9-18^{3}$ & 65 & 11 & 10 \\
\hline Limulus polyphemus & (4) & $19-23^{2}$ & 12 & 0 & \\
\hline Polinices duplicatus & (6) & $9-50^{3}$ & 12 & 0 & \\
\hline \multicolumn{6}{|c|}{1 Anterior shield length } \\
\hline \multicolumn{6}{|c|}{2 Carapace width } \\
\hline${ }^{3}$ Shell length & & & & & \\
\hline
\end{tabular}

by the lack of alternative prey. No depression in $C$. maenas' rate occurred when 200 Gemma gemma were added (ANOVA, $F_{1,10}=0.048, P=0.989$ ) even though $95 \%$ of the clams were eaten within 2 d. Alternative prey were not provided to $P$. longicarpus. The feces of both species were the color of the embryos and did not contain empty capsules nor recognizable fragments of capsule walls. Living larvae emerged from most of those capsules which were detached or broken by these 2 species (Table 2).

Table 2. Ilyanassa obsoleta. Percent of intact and broken egg capsules from which larvae successfully emerged. N: number of capsules examined; \%: percent with larvae emerging

\begin{tabular}{|lrrrrr|}
\hline \multirow{2}{*}{ Capsule condition } & \multicolumn{2}{c}{ Intact } & \multicolumn{2}{c|}{ Broken } \\
& N & $\%$ & \multicolumn{2}{c}{ N } & $\%$ \\
\hline Undisturbed & 106 & 97.1 & & \\
Carcinus detached & 25 & 93.1 & 25 & 72.7 \\
Pagurus detached & 25 & 94.0 & 25 & 64.3 \\
Littorina defecated & 16 & 56.2 & 87 & 0 \\
\hline
\end{tabular}

Littorina littorea destroyed an average of 11 capsules every $2 \mathrm{~d}$ (Table 1). The periwinkles attempted to engorge the capsules, usually breaking the wall and consuming the eggs. On occasion the entire capsule was swallowed. Most defecated capsules were broken and did not contain embryos. Larvae emerged from half of those defecated capsules which did not appear to be broken (Table 2).

Adult and juvenile Polinices duplicatus and juvenile Limulus polyphemus did not prey on egg capsules in the laboratory (Table 1). Few capsules were detached during numerous contacts by either of these species.

\section{Field Studies}

Carcinus maenas and Pagurus longicarpus were most numerous in the low intertidal Zostera bed and in the tide pools of the mid-intertidal zone (Table 3). Both species were active in the tide pools at low tide, and during high tides. Counts of $C$. maenas from a fixed location in the eelgrass beds during one flood tide ranged from 3 to $12 \mathrm{~min}^{-1}$. Few could be seen when swimming over the sand flat, and many remained within the perimeter of the tide pools. Both species were attracted to egg capsules, being more abundant on tube-caps with capsules attached than on tube-caps with Ilyanassa obsoleta or without capsules (Table 4). Littorina littorea was most numerous in and along the marsh, but also abundant throughout the intertidal zone, particularly on drift algae, wood, rocks, and tube-caps lacking adult IIyanassa (Tables 3 and 4). 
Table 3. Ilyanassa obsoleta. Densities and egg predators $0.25 \mathrm{~m}^{-2}$ (mean \pm 1 standard error) in Barnstable Harbor, June, 1981. N: number of quadrats censused. Relative abundance of Carcinus maenas determined from observations made at flood tide

\begin{tabular}{|c|c|c|c|c|c|}
\hline Location & $N$ & Ilyanassa & Littorina & pagurus & Carcinus \\
\hline \multicolumn{6}{|l|}{ Upper tidal zone } \\
\hline Marsh edge & 49 & $0.1 \pm 0.1$ & $46 \pm 3.0$ & $0.2 \pm 0.1$ & common \\
\hline $2-35 \mathrm{~m}$ from edge & 39 & $3.3 \pm 1.0$ & $2.8 \pm 1.0$ & $0.1 \pm 0.1$ & rare \\
\hline \multicolumn{6}{|l|}{ Mid tidal zone } \\
\hline Tide pools & 40 & $37 \pm 5.4$ & $2.3 \pm 0.4$ & $0.7 \pm 0.2$ & $0.3 \pm 0.1^{\circ}$ \\
\hline Exposed flats & 60 & $31 \pm 5.3$ & $1.7 \pm 0.4$ & $0.1 \pm 0.1$ & rare \\
\hline Low Zostera bed & 24 & 0 & $9.4 \pm 1.8$ & $4.3 \pm 1.8$ & common \\
\hline
\end{tabular}

Table 4. Densities of egg predators on, or immediately adjacent to, tube-caps of Diopatra cuprea which either lacked egg capsules, had Ilyanassa obsoleta actively depositing capsules, or had egg capsules but no I. obsoleta (mean \pm 1 standard error).

N: number of tube-caps examined

\begin{tabular}{|c|c|c|c|c|c|}
\hline Condition & $N$ & llyanassa & Littorina & Pagurus & Carcinus ${ }^{\circ}$ \\
\hline Without capsules & 24 & $1.2 \pm 0.2$ & $2.8 \pm 0.6$ & $0.8 \pm 0.3$ & $17 \%$ \\
\hline With Iyanassa & 62 & $97 \pm 6$ & $0.7 \pm 0.2$ & $0.5 \pm 0.1$ & $12 \%$ \\
\hline With capsules only & 70 & 0 & $2.5 \pm 0.3$ & $1.9 \pm 0.2$ & $36 \%$ \\
\hline
\end{tabular}

The high rates of egg predation measured in the laboratory raise the question as to whether these predators have similar effects in nature where alternative, and possibly more preferable prey items are available. The initial number of egg capsules on $5-\mathrm{cm}$ strands of Codium used in field caging experiments was determined to be approximately 1215 (243 \pm 12 capsules $\mathrm{cm}^{-1} ; \mathrm{n}=10$ ). After $10 \mathrm{~d}$, caged strands averaged 1103

Table 5. Ilyanassa obsoleta. Number of egg capsules (mean \pm 1 standard deviation) remaining on caged and uncaged strands of Codium fragile after $10 \mathrm{~d}$ in a tide pool (June, 1981). Fratio from Analysis of Variance

\begin{tabular}{lcccc|}
\hline Condition & $N$ & Capsules & Range & $F_{(1, i 2)}$ \\
\hline Caged & 6 & $1103 \pm 32$ & $989-1172$ & $16.72 \cdots$ \\
Uncaged & 8 & $572 \pm 108$ & $146-1040$ & \\
$\cdots \mathrm{p}=.0015$ & & & & \\
\hline
\end{tabular}

egg capsules (Table 5), an unexplained loss of $9 \%$ Strings binding the strands were probably responsible for this loss. Variability was small and no predators were seen within the cages. In contrast, variability among uncaged strands was large (Table 5). On the average, uncaged strands had $52 \%$ fewer egg capsules than caged strands. One uncaged strand lost $85 \%$, while another was not attacked by predators.
Littorina littorea was the most abundant egg predator in the mid-intertidal zone where most egg capsules were Iaid by llyanassa obsoleta. Two-week long photographic studies documented a decline in egg capsules from $80 \%$ to $30 \%$ by cover on the end of a log occupied by $L$. littorea. The other end, from which $L$. littorea were removed every 3 to $4 \mathrm{~d}$, increased capsule cover from $75 \%$ to $80 \%$ over this period.

\section{DISCUSSION}

In this study, mortality of benthic, encapsulated IIyanassa obsoleta larvae equalled or exceeded that during the planktonic phase: more than half of the larvae were eaten before the remaining emerged (Table 5). Spines on the capsules did not deter predation by Pagurus longicarpus and Carcinus maenas, but they may have interfered with egg consumption by Littorina littorea. Capsules protected embryos from digestion by L. littorea (Table 2). Pechenik (1979) suggests that encapsulation reduces mortality in the plankton since larvae spend less time at this vilnerable stage. However, selection did not appear to favor encapsulation in this study.

One explanation is that most of the predation was associated with introduced European species: Car- 
cinus maenas, the most voracious predator, and Littorina littorea, the most abundant predator (Tables 1, 3 and 4). C. maenas may have been introduced by ships to the mid-Atlantic coast in the 18th century, from where it spread north into New England (Verrill et al., 1874; Bryant, 1906; Chilton, 1910; Scattergood, 1952; Carlton, pers. comm.). L. littorea first appeared in Nova Scotia around 1840 and rapidly spread south into New Jersey (Dexter, 1961; Kraeuter, 1974; Carlton, 1982). Less obvious is that the third major predator, the indigenous hermit crab Pagurus longicarpus, is probably more abundant now than before the arrival of $L$. littorea (Carlton, 1982). According to Say (1822), P. Iongicarpus most frequently utilized shells of Myanassa obsoleta in the early 19th century, but now L. littorea shells are commonly used (Scully, 1979; Carlton, 1982). Unlike other hermit crab populations (e. g. Childress, 1972; Vance, 1972; Fotheringham, 1976), populations of $P$. longicarpus in New England are not limited by shell availability (Scully, 1979).

Several lines of evidence suggest that Pagurus longicarpus and Carcinus maenas are attracted to egg capsules, but that Littorina littorea is not. P. longicarpus, a micro-herbivore and scavenger (Allee and Douglas, 1945; Roberts, 1968; Scully, 1978), and C. maenas, primarily a molluscan predator (Ebling et al., 1964; Ropes, 1969), detached many egg capsules under laboratory conditions and later ate them. Both species also devoured the egg collars of Lunatia heros and Polinices duplicatus. In the field, both crustacean species were more abundant near tube-caps with egg capsules than without capsules (Table 4). L. littorea in contrast, did not ingest unattached capsules or egg collars in the laboratory, and was as abundant on tubecaps with egg capsules as those without (Table 4). The lower density of littorines on tube-caps with IIyanassa obsoleta present reflects the behavior of the adult mud snail, which actively avoids $L$. littorea (Brenchley, 1980, 1981). L. littorea, a herbivore (e. g. Lubchenco, 1978) incapable of digesting capsule walls (Table 2), inadvertently grazes upon the capsules because of their similarity to algal fronds or diatoms.

Ilyanassa obsoleta has not accomplished effective chemoreceptory responses in 30 generations to avoid the introduced predators, although its sense of chemoreception to prey and native predators is highly developed (Copeland, 1918; Carr, 1967; Brown, 1969; Crisp, 1969; Gurin and Carr, 1971; Atema and Burd, 1975; Stenzler and Atema, 1977). Unlike the European mud snail Nassarius reticulatus, the American species does not bury when the odor of Carcinus (European) is present (Atema and Stenzler, 1977; Crisp, 1978). Littorina also does not elicit an alarm response (Stenzler and Atema, 1977). In fact, I. obsoleta is somewhat attracted to crushed Littorina littorea (Snyder, 1967;
Atema and Burd, 1975). Laboratory studies show that physical contact, but not water soluble cues, cause $I$. obsoleta to delay egg laying when held with either $L$. littorea or Pagurus longicarpus (Brenchley, in prep.). The hermit crabs constantly handle the shells, and within 2 wk the shells are empty. Whether $P$. longicarpus eats $I$. obsoleta alive (Arnold, 1901) was not determined here, but the interaction probably occurs only in confinement

In addition, Ilyanassa obsoleta has not evolved an obvious life history response. A 2 to $4 \mathrm{wk}$ delay in the peak of activity during this study would have reduced the exposure of encapsulated larvae to predators by as much as $50 \%$ to $75 \%$. This is because development was arrested in early May and remained slow into June, when seawater temperatures rose from $13^{\circ} \mathrm{C}$ to $18^{\circ} \mathrm{C}$ (Scheltema, 1967). Yet, the predators were active and egg capsules were laid at $13^{\circ} \mathrm{C}$ in the laboratory (Table 1). Reproductive activity of $I$. obsoleta is triggered by rising seawater temperatures (Jenner, 1956; Scheltema, 1967; Sastry, 1971), and typically occurs early in the growing season. For example, egg laying begins in February in Beaufort, North Carolina (USA) and terminates there in May as it begins further north in Barnstable Harbor. Early reproduction prolongs only the encapsulated stage because, according to Scheltema (1967), by the time the larvae finally emerge, the sea will have warmed sufficiently to insure rapid development in the plankton. The emergence of the larvae would not be delayed, since development in capsules is slow or arrested during the period in question.

Co-evolutionary responses requiring genetic change will be slow to evolve in species like Ilyanassa obsoleta which are genetically homogeneous throughout their range (Gooch et al., 1972; Snyder and Gooch, 1973). Egg laying behavior of the marine gastropod Aplysia are genetically controlled (Scheller et al., 1982). A family of genes is responsible for both initiating egg laying and suppressing other activities, such as feeding and locomotion. Chemoreception is suppressed when $I$. obsoleta copulate (Stenzler and Atema, 1977). Thus, chemoreception, like egg laying, may be under genetic control and slow to evolve.

In contrast, avoidance behavior to introduced species evolves rapidly. Ilyanassa obsoleta was introduced to San Francisco Bay around 1905 (Carlton, 1979). The native gastropod Cerithidea californica now actively avoids $I$. obsoleta preying on its eggs and crawl-away larvae (Race, 1979). In New England, adult I. obsoleta actively migrate from tide pools where Littorina littorea are added, and migrate into marshes (Brenchley, 1980, 1982) and onto cobble beaches (Bertness, pers. comm.) when littorines are removed. The avoidance behavior is apparently ontogenetic, since 
juvenile I. obsoleta do not avoid L. Iittorea (Brenchley, in prep).

The change in distribution of Ilyanassa obsoleta in response to Littorina littorea suggests that habitat or substrate preferences are quick to evolve and thus not genetically determined. In laboratory studies of egg laying, $I$. obsoleta prefers the branching green alga Codium fragile and the eel grass Zostera marina over Spartina shoots, marsh peat, and rocks (Brenchley, 1981). C. fragile is transient and often free of littorines which interfere with egg laying. Yet, $C$. fragile has only been present in the Harbor since 1975, having spread north from south of Cape Cod, where it was presumably introduced from Europe (Carlton and Scanlon, in prep.). I. obsoleta lays egg capsules often 10 layers thick on $C$. fragile (Table 5). While this may increase the reproductive output of $I$. obsoleta populations, these concentrations attract Pagurus longicarpus and Carcinus maenas. Together with L. littorea, these predators can destroy at least half of the egg capsules laid on $C$. fragile during the peak of reproductive activity (Table 5).

Acknowledgements. This research was made possible by the support of STEPS fellowships from M. B. L. as well as faculty research and travel grants from U. C. I. Jim Carlton and Judy Grassle raised timely questions which Merryl Alber helped me answer. I thank Jim Carlton for pointing out to me that Littorina littorea, Carcinus maenas, and Codium fragile are introduced species. I also thank Jim Carlton, Alex Yourke, Ami Scheltema, Rudi Scheltema, Nancy Marcus and anonymous reviewers for comments and suggestions.

\section{LITERATURE CITED}

Adams, C. B. (1838). Observations on some species of the marine shells of Massachusetts, with descriptions of five new species. Boston J. Nat. Hist. 2: 262-288

Allee, W. C., Douglas, M. B. (1945). A dominance order in the hermit crab, Pagurus longicarpus Say. Ecology 26: $411-412$

Anderson, W. (1970). A preliminary study of the relationship of salt ponds and wildlife South San Francisco Bay. Calif. Fish Game 56: 240-252

Arnold, A. F. (1901). The sea-beach at ebb-tide, Century, New York

Ashkenas, L. R., Atema, J. (1978). A salt marsh predator-prey relationship: attack behavior of Carcinus maenas (L) and defenses of Ilyanassa obsoleta (Say). Biol. Bull. mar. biol. Lab., Woods Hole 155: 426

Atema, J., Burd, G. D. (1975). A field study of chemotactic responses of the mud snail, Nassarius obsoletus. J. chem. Ecol. 1: 243-251

Atema, J., Stenzler, D. (1977). Alarm substance of the marine mud snail, Nassarius obsoletus: biological characterization and possible evolution. J. chem. Ecol. 3: 173-187

Bayne, B. L. (1976). The biology of mussel larvae. In: Bayne, B. L. (ed). Marine mussels: their ecology and physiology. Cambridge University Press, Cambridge, IBP No. 10, pp. $81-120$
Brenchley, G. A. (1980). Distribution and migratory behavior of Ilyanassa obsoleta in Barnstable Harbor. Biol. Bull. mar biol. Lab. Woods Hole 159: 456-457

Brenchley, G. A. (1981). Limiting resources and the limits to reproduction in the "mud" snail Ilyanassa obsoleta in Barnstable Harbor, Massachusetts. Biol. Bull. mar, biol. Lab. Woods Hole 161323

Brenchley, G. A. (1982). The current status of the 100 year war between native "mud" snails and a dominant competitor and predator, Littorina littorea. Malacol. Rev. 15: 146

Brown, S. C. (1969). The structure and function of the digestive system of the mud snail. Nassarius obsoletus (Say). Malacologia 9: 447-500

Bryant, O. (1906). Recent extension of the range of the green crab. Am. Nat. 40: 382-383

Carlton, J. T. (1979). History, biogeography, and ecology of the introduced marine and estuarine invertebrates of the Pacific coast of North America, Ph. D. Dissertation, University of California, Davis

Carlton, J. T (1982). The historical biogeography of Littorina littorea on the Atlantic coast of North America, and implications for the interpretation of the structure of New England intertidal communities. Malacol. Rev. (in press)

Carr, W. E. S. (1967). Chemoreception in the mud snail Nassarius obsoletus. Biol. Bull. mar biol. Lab., Woods Hole 133: 90-127

Childress, J. R. (1972). Behavioral ecology and fitness theory in a tropical hermit crab. Ecology 53: 960-964

Chilton, C. (1910). Note on the dispersal of marine crustacea by means of ships. Trans. N. Z. Inst. 43: 131-133

Copeland, M. (1918). The olfactory reactions and organs of the marine snails Alectrion obsoleta (Say) and Busycon canaliculatum (Linn.). J. exp. Zool. 25: 177-227

Crisp, M. (1969). Studies on the behavior of Nassarius obsoletus (Say) (Mollusca, Gastropoda). Biol. Bull. mar biol. Lab., Woods Hole 136: 355-373

Crisp, M. (1978). Effects of feeding on the behavior of Nassarius species (Gastropoda: Prosobranchia). J. mar. biol. Ass. U. K. 58: 659-669

Dexter, R. W. (1961). Early records of Littorina Iittorea from the coast of Massachusetts. Nautilus 74: 120-121

Dimon, A. C. (1905). The mud snail: Nassa obsoleta. Cold Spring Harbor Monogr. 5: 1-50

Ebling, F. J., Kitching, J. A., Muntz, L., Taylor, C. (1964). The ecology of Louge Ine. 13. Experimental observations of the destruction of Mytilus edulis and Nucella lapillus by crabs. J. Anim. Ecol. 33: 73-82

Edwards, D. C. (1974). Preferred prey of Polinices duplicatus in Cape Cod inlets. Bull. Am. malacol. Union 1974: 17-20

Fotheringham, N. (1976). Hermit crab shells as a limiting resource. Crustaceana 31: 194-197

Fretter, V., Graham, A. (1962). British prosobranch molluscs, their functional anatomy and ecology, Ray Society, London

Gambino, J. J. (1959). The seasonal incidence of infection of the snail Nassarius obsoletus (Say) with larval trematodes. J. Parasit. 45: 440-456

Gooch, J. L., Smith, B. S., Knupp, D. (1972). Regional survey of gene frequencies in the mud snail, Nassarius obsoletus. Biol. Bull. mar biol. Lab., Woods Hole 142: 36-48

Green: R. H., Hobson, K. D. (1970). Spatial and temporal structure in a temperate intertidal community with special emphasis on Gemma gemma (Pelecypoda: Mollusca). Ecology 51: 999-1011

Grodhaus, G., Keh, B. (1958). The marine, dermatitis-producing cercaria of Austrobilharzia variglandis in California (Trematoda: Schistosomitidae). J. Parasit, 44:633-638 
Gurin, S., Carr, W E. (1971). Chemoreception in Nassarius obsoletus: the role of specific stimulatory proteins. Science, N. Y. 174: 293-295

Hunt, J. H. (1981). The importance of adult-larval interactions in determining abundance patterns of soft-sediment infauna. M. S. thesis, University of North Carolina, Chapel Hill

Hurst, A. (1965). The feeding habitats of Nassarius vibex (Say). Proc. malacol. Soc. Lond 36: 313-317

Jenner, C. E. (1956). The timing of reproductive cessation in geographically separated populations of Nassarius obsoletus. Biol. Bull. mar. biol. Lab., Woods Hole 111: 292

Kreauter, J. N. (1974). Offshore currents, larval transport, and establishment of southern populations of Littorina littorea Linne along the U. S. Atlantic coast. Thalassia jugosl. 10: $159-170$

Levinton, J. S. (1982). Marine ecology, Prentice-Hall, Englewood Cliffs, New Jersey

Lubchenco, J. (1978). Plant species diversity in a marine intertidal community: importance of herbivore food preference and algal competitive ability. Am. Nat. 112: 23-39

Mackenzie, C. L. (1961). Growth and reproduction of the oyster drill Eupleura caudata in the York River, Virginia. Ecology 42: 317-338

Mileikovsky, S. A. (1974). On predation of pelagic larvae and juveniles of marine bottom invertebrates by adult benthic invertebrates and their passing alive through their predators. Mar. Biol. 26: 303-311

Miller, H. M., Northup, F. E. (1926). The seasonal infestation of Nassa obsoleta (Say) with larval trematodes. Biol. Bull. mar. biol. Lab., Woods Hole 50: 490-508

Pechenik, J. A. (1975). The escape of veligers from the egg capsules of Nassarius obsoletus and Nassarius trivittatus (Gastropoda, Prosobranchia). Biol. Bull. mar. biol. Lab., Woods Hole 149: 580-598

Pechenik, J. A. (1978). Adaptations to intertidal development: studies on Nassarius obsoletus. Biol. Bull. mar. biol. Lab., Woods Hole 154: 282-291

Pechenik, J. A. (1979). Role of encapsulation in invertebrate life histories. Am. Nat. 114: 859-870

Pechenik, J. A. (1982). Ability of some gastropod egg capsules to protect against low-salinity stress. J. exp. mar. Biol. Ecol. (in press)

Perron, F. E. (1975). Carnivorous Calliostoma (Prosobranchia: Trochidae) from the northeastern Pacific. Veliger 18: $52-54$

Race, M. S. (1979). Interference competition between native and introduced mudsnails: an experimental study of the dynamics and mechanisms of displacement of Cerithidea californica by llyanassa obsoleta. Ph. D. dissertation, University of California, Berkeley

Recher, H. F. (1966). Some aspects of the ecology of migrant shorebirds. Ecology 47: 393-407

Roberts, M. H., Jr (1968). Functional morphology of mouth parts of the hermit crabs, Pagurus longicarpus and Pagurus pollicaris. Chesapeake Sci. 9: 9-20

Ropes, J. W. (1969). The feeding habits of the green crab, Carcinus maenas (L.). Fish. Bull. U. S. 67: 183-203

Say, T. (1822). An account of some of the marine shells of the United States. J. Philad. Acad. Nat. Sci. 2: 221-248

Sastry, A. N. (1971). Effect of temperature on egg capsule deposition in the mud snail, Nassarius obsoletus (Say). Veliger 13: 339-341

Scattergood, L. W. (1952). The distribution of the green crab, Carcinides maenas (L.) in the northwest Atlantic. Maine Dept. Sea Shore Fish., Fish. Circ. 8: 2-10

Schaefer, C. W., Milch, P., Levin, N. L. (1968). Effects of trematode infection on resistance of desiccation in the mud snail. Nassarius obsoletus (Say). Mar Biol. Assoc India, Symp. Ser. 3, Part 3: 805-813

Scheller. R. H., Jackson, J. F., McAllister, L. B., Schwartz, J. H., Kandel, E. R., Axel, R. (1982). A family of genes that codes for ELH, a neuropeptide eliciting a stereotyped pattern of behavior in Aplysia. Cell 208: 707-719

Scheltema, R. S. (1962). Pelagic larvae of New England intertidal gastropods. I. Nassarius obsoletus Say and Nassarius vibex Say. Trans. Am. Microbiol. Soc. 81: 1-11

Scheltema, R. S. (1964). Feeding habits and growth in the mud snail, Nassarius obsoletus. Chesapeake Sci. 5: 161-166

Scheltema, R. S. (1967). The relationship of temperature to the larval development of Nassarius obsoletus (Gastropoda). Biol. Bull. mar biol. Lab., Woods Hole 132: 253-265

Scully, E. P. (1978). Utilization of surface foam as a food source by the hermit crab, Pagurus longicarpus Say, 1817. Mar. Behav. Physiol. 5: 159-162

Scully, E. P. (1979). The effects of gastropod shell availability and habitat characteristics on shell utilization by the intertidal hermit crab Pagurus longicarpus Say. J. exp. mar. Biol. Ecol. 37: 139-152

Sindermann, C. J. (1960). Ecological studies of marine dermatitis producing schistosome larvae in northern New England Ecology 41: 670-684

Smith, B. S. (1980). The estuarine mud snail, Nassarius obsoletus: abnormalities in the reproductive system. J. mollusc. Stud. 46:247-256

Snyder, N. F. R. (1967). An alarm reaction of aquatic gastropods to intraspecific extract. Cornell U. Agric. Stat., Memoir 403: 1-122

Snyder, T P., Gooch, J. L. (1973). Genetic differentiation in Littorina saxatilis (Gastropoda). Mar. Biol. 22: 117-182

Stambaugh, J. E., McDermott, J. J. (1969). The effects of trematode larvae on the locomotion of naturally infected Nassarius obsoletus (Gastropoda). Penn. Acad. Sci. 43: 226-231

Stenzler, D., Atema, J. (1977). Alarm response of the marine mud snail, Nassarius obsoletus: specificity and behavioral priority. J. chem. Ecol, 3: 159-171

Stunkard, W. H. (1961). Cercaria dipterocerca Miller and Northup, 1926, and Stephanostomum dentatum (Linton, 1900), Manter, 1931. Biol. Bull. mar. biol. Lab., Woods Hole 120: 221-237

Tallmark, B. (1980). Population dynamics of Nassarius reticulatus (Gastropoda, Prosobranchia) in Gullmar Fjord, Sweden. Mar. Ecol. Prog. Ser. 3: 51-62

Thorson, G. (1950). Reproductive and larval ecology of marine bottom invertebrates. Biol. Rev. 25: 1-45

Tyron, G. W. Jr. (1882). Manual of chonchology, Vol. 4. G. W Tyron, Jr., Philadelphia

Vance, R. R. (1972). Competition and mechanism of coexistence in three sympatric species of intertidal hermit crabs. Ecology 53: 1062-1074

Vernberg, W B. (1969). Adaptations of host and symbionts in the intertidal zone. Am. Zool. 9: 357-365

Verrill, A. E., Smith, S. I., Harger, O. (1874). Catalogue of the marine invertebrate animals of the southern coast of New England and adjacent waters. In: Verrill, A. E., Smith, S. I. (eds.) Report upon the invertebrate animals of Vineyard Sound and adjacent waters. U. S. Government Printing Office, Washington, D. C., pp. 343-453

Wilson, W. H. Jr. (1980). A laboratory investigation of the effect of a terebellid polychaete on the survivorship of nereid polychaete larvae. J. exp. mar. Biol. Ecol. 46: 73-80

Woodin, S. A. (1976). Adult-larval interactions in dense 
infaunal assemblages: patterns of abundance. J. mar. Res. 34: $25-41$

Woodin, S. A. (1979). Settlement phenomena: the significance of functional groups. In: Stancyk, S. E. (ed.). Reproductive ecology of marine invertebrates. University of South Carolina Press, Columbia, pp. 99-106

This paper was presented by Dr R. S. Scheltema; it was accepted for printing on June 16, 1982 